\title{
"Funny Little Ground Owl"
}

By HUGH McLAUGHLIN, Lewvan, Sask.

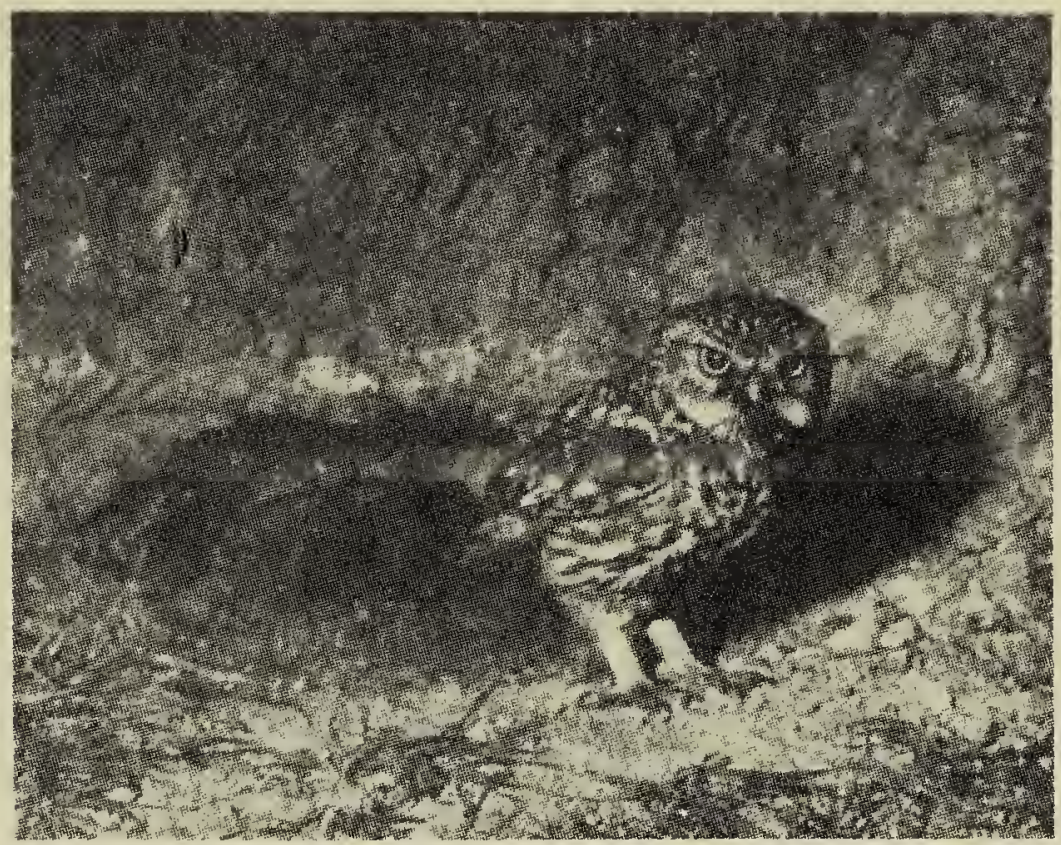

There is a shrill wailing in the still summer night - quite haunting and out of place it seems. Visions of the source seemed to conjure a water bird, long-legged and restless. But why would such a bird be active at night? It was finally discovered that the wailing one was a Ground Owl, and that its nocturnal noises were quite in line with owl activities.

They are quite a curiosity, as though Mother Nature had said, "We will make this one different." Other owls are not very noticeable except in flight, while these little sentinels perch on the mound - generally thrown up by a gopher, beside the hole which contains the nest. Quite the determined little birds they are. One summer they contested keenly with the gophers for a choice knoll and the accompanying hole. What went on below ground I do not know. There was evidence of trouble in the nest and only a couple of owls hatched the first clutch. Above ground, the gophers would chase them into a short flight, but they never left and eventually the feud simmered and the owls and gophers raised their families twenty feet apart.

The baby owls sit in a little row and there is much excitement when one of the parents returns home to distribute food. They are quite hard to approach and quickly disappear down the hole. The best view I ever had was when on horseback I could get close, as they were accustomed to grazing animals. As they grow larger, (like adolescent children) they seem to be more reluctant to go underground at the first warning of the parents. The retreating heads and scolding parents present quite a family scene.

From now on life is more hazardous - they leave home. An open hole seems an invitation. Once I had discovered two that had walked through a small hole in the top of a cistern to their watery death. They apparently like to hunt mice along the roadside. The mice, scurrying from one side of the road to the other, as we often see them at night by car light, are quite exposed for a few seconds to the owls, and is the only reason I can see for their choice of spot to spend the evening. For this reason, approaching cars take quite a toll - and flat bodies, belying the appearance of size created by feathers, dry into dust.

But some grow up, out of two hatches a summer, and in the colder fall the little family gather again around the ancestral home. They perch together now of course, and fly away instead of retreating underground. Home is the focal point of existence until practically freeze up, when they migrate. The same hole may be occupied several years in a row as family quarters. 